\title{
The effect of the marketing mix on the demand of Thai and foreign tourists
}

\author{
Sakkarin Nonthapot ${ }^{a^{*}}$ and Wanlapa Thomya ${ }^{a}$
}

\begin{tabular}{|c|c|}
\hline CHRON I CLE & A B S T RACT \\
\hline $\begin{array}{l}\text { Article history: } \\
\text { Received: March 12, } 2020 \\
\text { Received in revised format: } \\
\text { March } 272020 \\
\text { Accepted: March 29, } 2020 \\
\text { Available online: } \\
\text { April 2, } 2020 \\
\text { Keywords: } \\
\text { Border tourism } \\
\text { Tourism Marketing } \\
\text { GMS } \\
\text { Mekong tourism }\end{array}$ & $\begin{array}{l}\text { This research aimed to analyze the influence of the marketing mix on the demand of Thai and } \\
\text { foreign tourists along the Mekong Riverside in Nong Khai and Bueng Kan provinces, Thailand that } \\
\text { linked to the Lao People's Democratic Republic (Lao PDR), in particular the Vientiane Capital and } \\
\text { Bolikhamxay province. Questionnaires were used to collect the data from } 410 \text { samples selected by } \\
\text { convenience sampling. The data were analyzed via structural equation modeling (SEM) with the } \\
\text { WarpPLS } 6.0 \text { program. The results showed that the marketing mix comprising product, price, pro- } \\
\text { motion, and process affected the demand of tourists. In consequence, the tourism-related units of } \\
\text { Thailand and Lao PDR should focus on a touristic marketing strategy by conserving the standard } \\
\text { of the tourist attractions, touristic marketing promotion, and an appropriate price. Moreover, the } \\
\text { related stakeholders should become aware of providing services to tourists as means to respond to } \\
\text { the demand of Thai and foreign tourists. }\end{array}$ \\
\hline
\end{tabular}

C 2020 by the authors; licensee Growing Science, Canada

\section{Introduction}

The tourism sector is an industry that plays a major role in the economic system in every country worldwide, as it connects to several types of businesses including tour guides, accommodation, transport, food and entertainment, and souvenirs. When tourism expands, this would positively affect the economic and social systems resulting in increased employment. Moreover, this leads to economic development and supports a country's overall growth. With regards to the tourism economic review of Thailand for 2018, the number of foreign tourists totaled 38.27 million, an increase of $7.54 \%$ compared to the previous year generating two trillion Baht in income, or a growth rate of $9.63 \%$. Simultaneously, Thai tourists created income of 1.06 trillion Baht. Thus, the total income for 2018 was 3.07 trillion Baht (Ministry of Sports and Tourism, 2019). As for tourism in the Northeastern region in 2016, there were 37.2 million visitors (Ministry of Sports and Tourism, 2017) due to the fact that the province cluster in this region had many tourist attractions. Furthermore, on 12 May, 2016, the National Tourism Policy Committee announced the tourism development area of Nong Khai, Loei, Bueng Kan, Mukdahan, and Nakhon Phanom provinces as a local lifestyle tourism development in the Kong River zone, as these provinces are located opposite the Lao People's Democratic Republic and the Kong River is the boundary (National Tourism Policy Committee, 2016). This zone has since been elevated as a strategy of the provincial cluster (Nonthapot et al., 2019; Ka - Kan -dee \& Nonthapot, 2020) since it demonstrates a superior position in the tourism development of the two countries. When considering the tourism capacity of this region, it is obvious that the provinces in which their territory connects to the Kong River, especially Nong Khai province, Thailand and Vientiane Prefecture, Lao People's Democratic Republic., and Bueng Kan province, Thailand and Bolikhamxay

\footnotetext{
* Corresponding author

E-mail address: sakkno@kku.ac.th (S. Nonthapot) 
province, Lao People's Democratic Republic, there are tourist attractions related to nature, outstanding culture with eye-catching itineraries. As such, this prompts the opportunity in developing the locations of Nong Khai province and Vientiane Prefecture, and Bueng Kan province and Bolikhamxay province to have the tourism capacity to link the two countries together.

Fig. 1 demonstrates the number of Thai and foreign tourists traveling to the four areas of the two countries in which the trend shows an increase every year. This reflects that these locations have good tourism competency and can respond to the demand of tourists. Additionally, tourists are eager to go out for entertainment and travel, as they intend to discover new different experiences, have an adventure, and to use new technology and innovations while traveling; as a consequence, this is in response to the demand for traveling (Kritsanaprakornkit, 2016).

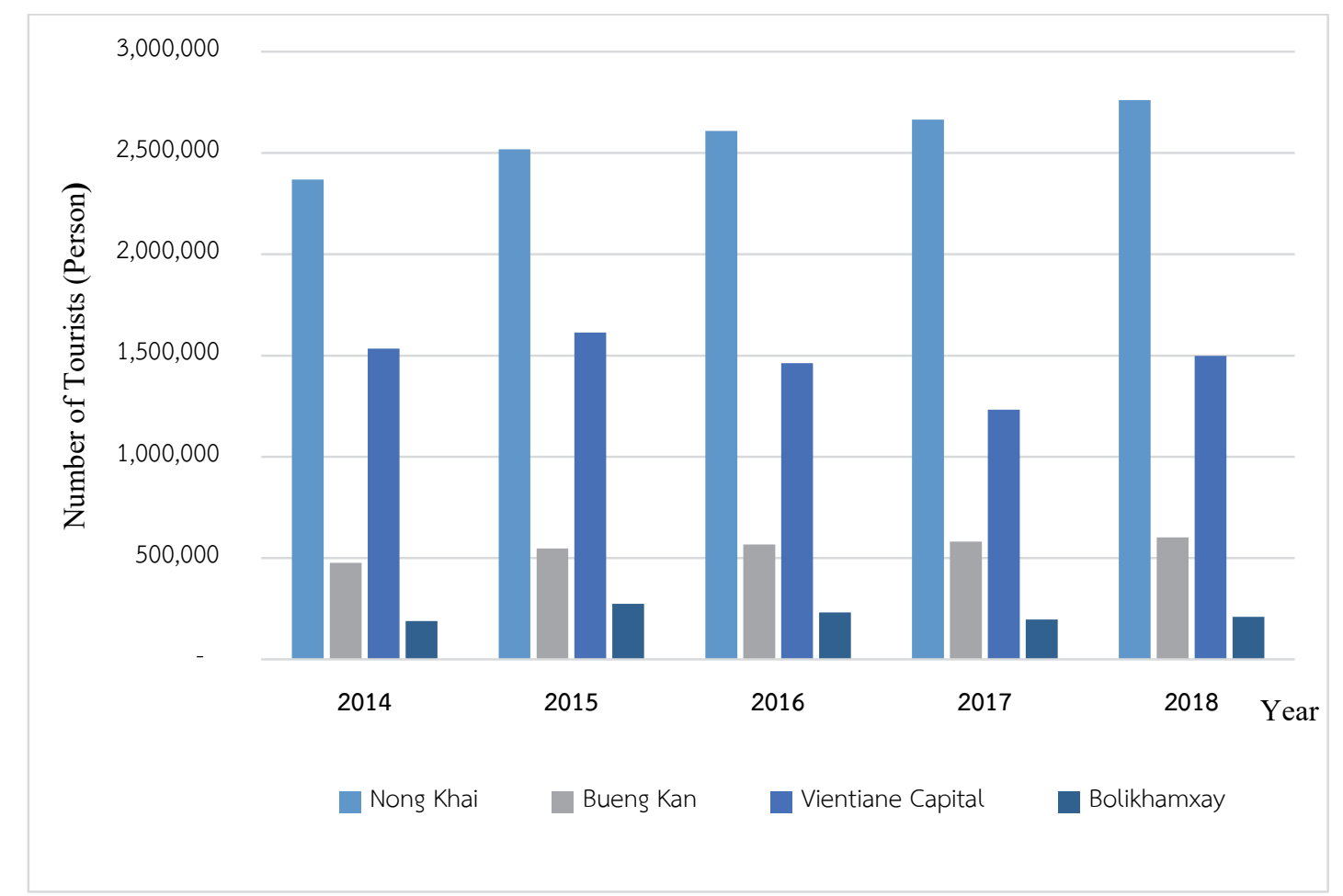

Source: Thailand's Department of Tourism (2019)

Ministry of Information, Culture, and Tourism (2019)

Fig. 1. Number of Thai and foreign tourists who visited Nong Khai, Bueng Kan, Vientiane Capital, and Bolikhamxay

In the development of a tourism zone, there is a need to study the demand of tourists. Therefore, the related units could appropriately respond to that demand. Nevertheless, the aforementioned areas were never studied in terms of touristic marketing and the demand for tourism by applying these aspects as the guidelines to promote tourism in the two countries. The marketing tools that are often used in studying the demand of consumers are the 7Ps marketing mix (Barghi et al., 2012; Magatef, 2015; Suphanthong, 2008; Taburi, 2006). This is the main factor that is often applied to respond to the demand of Thai and foreign tourists for traveling in Thailand and the Lao People's Democratic Republic. Simultaneously, the demand of the new generation of tourists in the future will rely more on new technology and innovation. At present, the tourist group consisting of a large population that will greatly influence tourism is the millennials (Burkhard, 2017). Hence, a study should be undertaken on the influence of the marketing mix on the demand of Thai and foreign tourists in Nong Khai and Bueng Kan provinces that link to Vientiane Capital and Bolikhamxay province, Lao People's Democratic Republic, as the guidelines for planning strategy that could promote the tourism marketing on the two sides of the Kong River and also codevelop tourism.

\section{Literature Review}

Most past research studies about tourism marketing applied the 7Ps marketing mix strategy to analyze the market. Various studies that focused on tourism marketing strategy (Barghi et al., 2012 ; Magatef, 2015 ; Suphanthong, 2008; Taburi, 2006) found that it was comprised of the following components: 1. Product: the tourist attraction would be developed appropriately to support tourists and the new places would be urgently improved for gaining the competency in further supporting tourism. 2. Price would be set in compliance with the product and service quality and significantly concern generating income from tourism. 3. Places for buying tourism products and services of each province through the Internet would not only offer facilities, but also conduct the public relations and promotion. 4. Promotion would be the added information of each province by 
organizing special activities. 5. People who provide services to tourists would have the trained skills for standard services and creating the satisfaction of tourists. 6. Physical evidence and presentation would add public relations through press media domestically and internationally. 7. Process would connect the provincial tourism management of a local administrative organization, the state sector, and the private sector altogether. In terms of the concepts relating to the demands of tourists, Wannathanom (2009), and Singsaktrakul and Sermkarndee (2013) found that the demand of tourists consisted of tourist attractions, tourism management; such as, facilities and security, activities and tourism processes; such as, a tour guide, and tourism participation. While, Burkhard (2017) considered the inclination of tourists' future demand, it was found to have originated from the following factors: (1) new technology and innovation link to tourism. (2) The lifestyle of the millennials considerably influences tourism because they are a large population group. (3) The interest of adventure tourism to find experience by themselves. (4) Women are deciding to travel more. (5) Gastronomy tourism is showing a popular trend. (6) Work and travel tend to continuously increase. (7) Health tourism. (8) Tourism that concerns the human relations of employees and the local people. (9) Tourists tend to view nature conservation as important. Nevertheless, Nonthapot et al. (2019) applied a confirmatory factor analysis (CFA) in a study of Thailand and the Lao People's Democratic Republic and found that the demands of tourists could be divided into three components: 1) Human relations, 2) Life experience, and 3) Recreation. Additionally, Pengprapai (2013)'s study on the marketing mix that influenced Thai and foreign tourists discovered that the aspects of the tourism marketing mix comprising product, people, and promotion had a positive influence while price and process had a negative influence with statistical significance toward the demand of social tourism activities of Phangan Island. Kamau et al. (2015) studied the effect of the marketing mix toward the accommodation selection of tourists in Kenya. They realized that the price of the product/service, place, process, and physical appearance were a priority in the tourist's decision when selecting accommodation in Kenya. Matchariyakul (2016) studied the factor affecting the independent travel decision of Thai tourists selecting Taiwan as a destination, and this demonstrated that the marketing mix that affected their decision was various products, appropriate price, promotions, good experience with the people, process about travel convenience and facilities in Taiwan, and physical evidence of Taiwan's overview. Simultaneously, the study of the behavior and marketing mix affecting Thai style tourism of foreign tourists represented that the overall marketing mix affected their decision at a good level (Pongwiritthon et al., 2016). As aforementioned, this demonstrated that the demand of tourists was set by the main factors of the global tourism trends (Burkhard, 2017; Vinaisatien, 2017), and it would influence the tourism marketing mix (7Ps) (Kamau et al., 2015; Matchariyakul, 2016; Pengprapai, 2013). As a result, the tourism marketing mix concept and the demand of tourists in Nong Khai and Bueng Kan provinces that linked to the Lao People's Democratic Republic could be concluded as shown in Fig. 2.

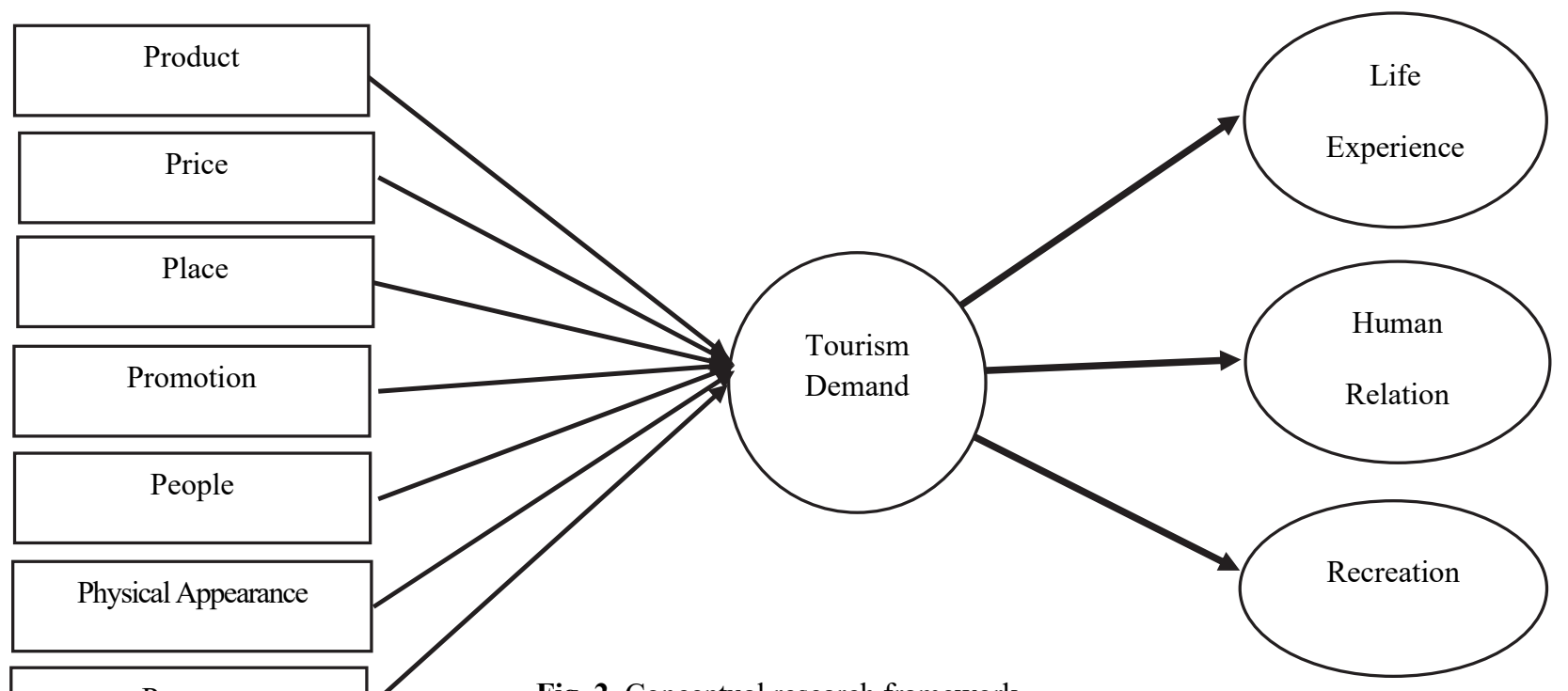

Process

Fig. 2. Conceptual research framework

\section{Methodology}

The population in this study were Thai and foreign tourists who visited Nong Khai province, Thailand and Vientiane Prefecture, Lao People's Democratic Republic and Bueng Kan province, Thailand and Bolikhamxay province, Lao People's Democratic Republic. From the statistics reports of 2018, the number of Thai and foreign tourists visiting these locations totalled 5,071,244 (Ministry of Information, Culture and Tourism, 2018; Thailand's Department of Tourism, 2019). The sample group in this research included Thai and foreign tourists who visited Nong Khai and Bueng Kan provinces, Vientiane Prefecture, and Bolikhamxay province in 2018. The reliability of the sample group was set at $95 \%$, which was a result from 400 samples (Yamane, 1967 cited in Tanmavad, 2002: 114). Nevertheless, to obtain a reliable statistical assessment from a higher power of test (Gravetter \& Wallnau, 2007. Therefore, this study fixed the sample size to be 410 samples. The convenience sampling 
selected the samples randomly in the tourist attraction area regarding the proportion of the population as shown in Table 1 . Additionally, the zones for sampling consisted of natural tourist attractions, artificial tourist attractions, and other tourist attractions. The tourist attractions were selected from the tourism database of Thailand 2017 and the 2016 list of the Ministry of Information, Culture, and Tourism of Lao PDR. The selected attractions were located along the two sides of the Kong River in the four locations.

Table 1

Proportion of the Samples

\begin{tabular}{clcccc}
\hline \multirow{2}{*}{ Rank } & \multicolumn{1}{c}{ Areas } & Thai Sample & Foreign Sample & Total & $\begin{array}{c}\text { Number of Attrac- } \\
\text { tions }\end{array}$ \\
\hline 1 & Nong Khai & 167 & 47 & 214 & 10 \\
2 & Bueng Kan & 46 & 1 & 47 & 7 \\
3 & Vientiane Capital & 67 & 53 & 120 & 9 \\
4 & Bolikhamxay & 2 & 17 & 19 & 4 \\
\hline
\end{tabular}

Source: Calculation.

The structural questionnaire was the tool that the author created in accordance with the objective of the study. This contained both close-ended and opened-ended questions. The tool was divided into three parts as follows:

Part 1. General Information of the Respondents

Part 2. Demand of Tourists who traveled

Part 3. Opinion from the Evaluation of the Tourism Marketing Mix.

In Parts 2 and 3, the author used a five-point Likert scale to assess the tourists' opinion according to RuelNovabos et al. (2015) (Table 2).

Table 2

Opinion scales of Thai and foreign tourists

\begin{tabular}{lcc}
\hline & Demand Scale/Priority of Tourists & Score \\
\hline Most & 5 & \\
More & 4 & 3 \\
Moderate & 2 \\
Low & 1 \\
Lowest & 2 & \\
\hline
\end{tabular}

Source: RuelNovabos et al. (2015)

The author used a questionnaire to collect the data from Thai and foreign tourists who visited Nong Khai province and Vientiane Prefecture, and Bueng Kan and Bolikhamxay provinces. The data from the 30 samples were tested to find the completeness of the questionnaire and to validate the reliability by using Cronbach's alpha and validity. The index of item-objective congruence (IOC) from five experts was taken into consideration for consistency. Every question had to have an IOC higher than 0.80. After testing, the questions were checked for reliability by using Cronbach's alpha; the result was 0.933 (Hair et al., 2014). In consequence, this represented that the tool was reliable. After that, the author collected 410 samples from men and women aged 18 years and over. The analysis of the influence of the marketing mix on the demand of Thai and foreign tourists in Nong Khai and Bueng Kan provinces that linked to the Lao People's Democratic Republic applied the data from the questionnaire asking to evaluate the marketing mix that consisted of 1. Product, 2. Price, 3. Place, 4. Promotion, 5. People, 6. Physical Appearance, and 7. Process. As for the opinion relating to the demand of tourists, this consisted of 1. Life Experience, 2. Recreation, and 3. Human Relations. Thus, Life Experience was composed of 1. presenting one's knowledge, lifestyle, and traveling experience, and 2.experiencing the diversity of food or local foods. Recreation was composed of 1. using new technology and innovation in tourism activities, 2.working and traveling, and 3.traveling for better health and better mind. Human Relations were composed of 1.the tourism that focused on human relations with the local people, and 2.new friendships with other travelers. The data were processed to find the confirmatory factor analysis (CFA) from the structural equation modeling (SEM) by using the Warp PLS 6.0 program.

\section{Results}

The demographic overview of Thai and foreign tourists who traveled in the mentioned areas demonstrated the majority of Thai tourists were female aged 20-30 years. Most traveled from the Northeastern region of Thailand and traveled by themselves. Most of them had graduated with an undergraduate degree, and more than half were employed as government officials or state enterprise officials. The mean of the tourists' income was THB 10,000 per month. On the other hand, most foreign tourists were female aged 20-30 years. Most travelers were from France and without a tour guide. The majority of them had graduated higher than an undergraduate degree and were employed in a private company. More than half earned 
THB 50,000 per month. According to the CFA of the influence of the marketing mix on the demand of Thai and foreign tourists in Nong Khai and Bueng Kan provinces that linked to the Lao People's Democratic Republic, the result of the model showed that the average path coefficient $(\mathrm{APC})=0.29(\mathrm{P}<0.001)$, average R-square $=0.46(\mathrm{P}<0.01)$, average block VIF $(\mathrm{AVIF})=1.78, \mathrm{GoF}=0.53, \mathrm{SPR}=1.00, \mathrm{RSCR}=1.00$, and $\mathrm{SSR}=1.00$, which represented the appropriateness of the model as shown in Table 3.

Table 3

$\underline{\text { Result of the model assessment }}$

\begin{tabular}{|c|c|c|c|}
\hline Values for Assessment & Value & $\begin{array}{l}\text { Significance/ } \\
\text { Principle }\end{array}$ & Result \\
\hline Average path coefficient (APC) & 0.29 & $\mathrm{P}<0.001$ & Slightly \\
\hline Average R-squared (ARS) & 0.46 & $\mathrm{P}<0.001$ & Slightly \\
\hline Average block VIF (AVIF) & 1.78 & $\begin{array}{l}\text { acceptable if }<=5, \\
\text { ideally }<=3.3\end{array}$ & Accepted \\
\hline Goodness of Fit GoF (GoF) & 0.53 & $\begin{array}{l}\text { Small }>=0.1, \text { medium }>= \\
0.25 \\
\text { large }>=0.36\end{array}$ & Large \\
\hline Sympson's paradox ratio (SPR) & 1.00 & $\begin{array}{l}\text { acceptable if }>=0.7 \text {, } \\
\text { ideally }=1\end{array}$ & Accepted \\
\hline R-squared contribution ratio (RSCR) & 1.00 & $\begin{array}{l}\text { acceptable if }>=0.9, \\
\text { ideally }=1\end{array}$ & Accepted \\
\hline Statistical suppression ratio (SSR) & 1.00 & acceptable if $>=0.7$ & Accepted \\
\hline
\end{tabular}

Source: Calculation

The appropriateness of the model to create the reflective model required convergent validity and discriminant validity by convergent validity. The criteria were the indicator loading that had to be higher than 0.60 , and every statistical significance (as at $95 \%$ of reliability) reflected the convergent validity (Henseler et al., 2009; Lauro \& Vinzi, 2004). The analytical result is displayed in Table 4.

Table 4

Convergent validity of the reflective latent measurement model.

\begin{tabular}{|c|c|c|c|}
\hline Construct & $\begin{array}{c}\text { loadin } \\
\mathbf{g}\end{array}$ & S.E. & P-value \\
\hline \multicolumn{4}{|l|}{ Life Experience } \\
\hline 1. To present one's knowledge, lifestyle, and travel experience. & 0.81 & 0.04 & $<0.01$ \\
\hline 2. To experience the diversity of food or local food. & 0.81 & 0.04 & $<0.01$ \\
\hline \multicolumn{4}{|l|}{ Recreation } \\
\hline 1. To use new technology and innovation in the tourism activities. & 0.70 & 0.05 & $<0.01$ \\
\hline 2. To work and travel. & 0.78 & 0.04 & $<0.01$ \\
\hline 3. To travel for better health and better mind. & 0.75 & 0.05 & $<0.01$ \\
\hline \multicolumn{4}{|l|}{ Human Relations } \\
\hline 1. Tourism that focuses on human relations with the local people. & 0.90 & 0.04 & $<0.01$ \\
\hline 2. New friendships with other travellers. & 0.90 & 0.04 & $<0.01$ \\
\hline \multicolumn{4}{|l|}{ Demand } \\
\hline 1. Life experience & 0.67 & 0.05 & $<0.01$ \\
\hline 2. Recreation & 0.71 & 0.05 & $<0.01$ \\
\hline 3. Human relations & 0.79 & 0.04 & $<0.01$ \\
\hline \multicolumn{4}{|l|}{ Product } \\
\hline 1. Beautiful tourist attractions & 0.82 & 0.04 & $<0.01$ \\
\hline 2. Diversity of tourist attractions & 0.78 & 0.04 & $<0.01$ \\
\hline 3. Reputative sites of history, culture, and traditions. & 0.76 & 0.05 & $<0.01$ \\
\hline 4. Natural tourist attractions in the area are popular. & 0.74 & 0.05 & $<0.01$ \\
\hline 5. Sufficient full facilities for tourism. & 0.66 & 0.05 & $<0.01$ \\
\hline \multicolumn{4}{|l|}{ Price } \\
\hline 1. Price/fee is appropriate. & 0.77 & 0.05 & $<0.01$ \\
\hline 2. Price of the traveling program is appropriate. & 0.79 & 0.04 & $<0.01$ \\
\hline 3. Room rate is appropriate. & 0.83 & 0.04 & $<0.01$ \\
\hline 4. Food price is appropriate. & 0.82 & 0.04 & $<0.01$ \\
\hline 5. Souvenir price is appropriate. & 0.60 & 0.05 & $<0.01$ \\
\hline 6. Transport price accessing to the sites is appropriate. & 0.78 & 0.04 & $<0.01$ \\
\hline \multicolumn{4}{|l|}{ Place } \\
\hline 1. Be able to purchase a travel program directly with a tour agency. & 0.87 & 0.04 & $<0.01$ \\
\hline 2. Be able to purchase a travel program with a representative. & 0.88 & 0.04 & $<0.01$ \\
\hline 3. Be able to book a travel program and accommodation through the Internet. & 0.73 & 0.05 & $<0.01$ \\
\hline
\end{tabular}


Table 4

Convergent validity of the reflective latent measurement model (Continue)

\begin{tabular}{|c|c|c|c|}
\hline Construct & loading & S.E. & P-value \\
\hline \multicolumn{4}{|l|}{ Promotion } \\
\hline 1. Advertise through the Internet, television, newspaper, and brochure. & 0.70 & 0.05 & $<0.01$ \\
\hline 2. Discount from a tour agency. & 0.72 & 0.05 & $<0.01$ \\
\hline 3. Public relations in the local area. & 0.79 & 0.04 & $<0.01$ \\
\hline 4. A festival has been organized to promote tourism. & 0.79 & 0.04 & $<0.01$ \\
\hline 5. Study the information from the rating, score, and review of the site. & 0.72 & 0.05 & $<0.01$ \\
\hline 6. Interesting public relations through media, television, and radio. & 0.74 & 0.05 & $<0.01$ \\
\hline \multicolumn{4}{|l|}{ People } \\
\hline 1. A sufficient number of security guards and service providers. & 0.82 & 0.04 & $<0.01$ \\
\hline 2. The security guards and service providers have a good service mind. & 0.86 & 0.04 & $<0.01$ \\
\hline 3. Communication of the service providers in the tourist attractions. & 0.80 & 0.04 & $<0.01$ \\
\hline 4. Personality of the service providers. & 0.79 & 0.04 & $<0.01$ \\
\hline 5. Readiness of food sellers or restaurants/souvenir shops. & 0.62 & 0.05 & $<0.01$ \\
\hline \multicolumn{4}{|l|}{ Physical Appearance } \\
\hline 1. Large and sufficient parking lots. & 0.65 & 0.05 & $<0.01$ \\
\hline 2. Have clear signages. & 0.80 & 0.04 & $<0.01$ \\
\hline 3. Have toilets that are sufficient, clean, and convenient. & 0.78 & 0.04 & $<0.01$ \\
\hline 4. Have clear and understandable itinerary signs. & 0.82 & 0.04 & $<0.01$ \\
\hline $\begin{array}{l}\text { 5. Have a public relations and tourism information center, which is visible and } \\
\text { easy to find. }\end{array}$ & 0.70 & 0.05 & $<0.01$ \\
\hline 6. Have sufficient accommodation to support the number of tourists. & 0.60 & 0.05 & $<0.01$ \\
\hline \multicolumn{4}{|l|}{ ( } \\
\hline 1. Manners and friendliness of the local people. & 0.63 & 0.05 & $<0.01$ \\
\hline 2. Security of life and property. & 0.74 & 0.05 & $<0.01$ \\
\hline $\begin{array}{l}\text { 3. The tourist attraction has a facility management process; for example, provides } \\
\text { parking lots. }\end{array}$ & 0.70 & 0.05 & $<0.01$ \\
\hline $\begin{array}{l}\text { 4. The tourist attraction has a public relations staff management process to help } \\
\text { tourists. }\end{array}$ & 0.82 & 0.04 & $<0.01$ \\
\hline 5. The tourist attraction has a fast security management process for tourists. & 0.82 & 0.04 & $<0.01$ \\
\hline $\begin{array}{l}\text { 6. The tourist attraction has natural/cultural management and conservation } \\
\text { processes. }\end{array}$ & 0.70 & 0.05 & $<0.01$ \\
\hline
\end{tabular}

Source: Calculation

From Table 4, Life Experience was composed of presenting one's knowledge, lifestyle, and travel experience, as well as experiencing the diversity of food or local food. Recreation was composed of using new technology and innovation in tourism activities, going for work and travel, and traveling for better health and better mind. Human Relations were composed of tourism that focused on human relations with the local people and new friendships with other travelers. The Demand for tourism consisted of life experience, recreation, and human relations. Product consisted of the following variables: beautiful tourist attraction, diversity of tourist attractions, reportative sites of history, culture, and traditions, popular natural tourist attractions in the area, and sufficient full facilities for tourism. Price was composed of the following variables: appropriate price/fee, appropriate price of the travel program, appropriate room rate, appropriate food price, appropriate souvenir price, and appropriate transport price. Place consisted of the following variables: ability to purchase a travel program directly with a tour agency, to purchase a travel program with a representative, and to book a travel program and accommodation through the Internet. Promotion was composed of the following variables: to advertise through the Internet, television, newspaper, and brochure, to obtain a discount from a tour agency, to do public relations in the local area, to organize a festival for promoting tourism, to study the information from the rating, score, and review about the site, and to do public relations through the media, television, and radio for persuasion. People consisted of the following variables: sufficient security guards and service providers, received good service from the security guards and service providers, the ability to communicate with tourists in the tourist attractions, good personality, and readiness of food sellers or restaurants/souvenir shops. Physical Appearance comprised the following variables: large and sufficient parking lots, clear signage, sufficient, clean, and convenient toilets, unambiguous and understandable itinerary signs, easy-to-find public relations and tourism information center, and sufficient accommodation to support tourists. Process consisted of the following variables: manners and friendliness of the local people, security of life and property, facility management in tourist attractions; for example, provide parking lots, having a public relations staff management process to help tourists, having a fast security management process for tourists, and having natural/cultural management and conservation processes. The measurement of the latent variables had loading starting from .60 and significance at $99 \%$ of the reliability. Thus, it was regarded that the model contained convergent validity. For the discriminant validity of the latent variables in the reflective model and correlation of the variables, the reliability of the measurement was considered from the composite reliability $(\mathrm{CR})>0.60$, average variance extract $(\mathrm{AVE})>0.50$, Cronbach's 
alpha $>0.60, \mathrm{Q}^{2}>0$ and $\mathrm{R}^{2}>0.20$ (Henseler et al., 2009; Lauro and Vinzi, 2004). As can be seen in Table 5, the CR was higher than 0.60. All the variables had an AVE higher than 0.50, Cronbach's alpha was higher than 0.60, and $\mathrm{Q}^{2}$ was higher than 0 . As a result, this indicated that the model could predict the endogenous variable (Chin, 1998a). Moreover, when $\mathrm{R}^{2}$ was higher than 0.30 , this demonstrated that the $\mathrm{R}^{2}$ values for the endogenous latent variables were assessed to be substantial (Chin, 1998b). Therefore, this could explain that the assessment result by PLS-SEM was reliable.

Table 5

Discriminant validity

\begin{tabular}{lcccccc}
\hline \multicolumn{1}{c}{ Construct } & CR & $\mathbf{R}^{2}$ & AVE & Cronbach Alpha & $\mathbf{Q}^{2}$ \\
\hline Lifeexp & 0.79 & 0.46 & 0.65 & 0.60 & 0.46 \\
Recreati & 0.79 & 0.47 & 0.55 & 0.60 & 0.47 \\
Humanre & 0.89 & 0.61 & 0.81 & 0.76 & 0.61 \\
Demand & 0.77 & 0.31 & 0.53 & 0.60 & 0.31 \\
Product & 0.87 & - & 0.57 & 0.81 & - \\
Price & 0.90 & - & 0.59 & 0.86 & - \\
Place & 0.87 & - & 0.69 & 0.77 & - \\
Promo & 0.88 & - & 0.56 & 0.84 & - \\
People & 0.89 & - & 0.61 & 0.83 & - \\
Physical & 0.87 & - & 0.53 & 0.82 & - \\
Process & 0.88 & - & 0.54 & 0.83 & - \\
\hline Sourc: Calcul
\end{tabular}

Source: Calculation

Table 6 reveals that the cross construct correlation as the square root of the AVE in the parentheses had a higher value than every other AVE. As a result, the table showed the discriminant validity in every construct as the square root of the AVE to be higher than every other measurement. In consequence, the measurement with a discriminant validity in this research was reliable. According to the analytical result in Figure 3, the tourism marketing mix influenced the demand of Thai and foreign tourists in Nong Khai and Bueng Kan provinces that linked to the Lao People's Democratic Republic. The factors of the marketing mix were Product, Price, Promotion, and Process, which affected the demand of tourists while Promotion had the most influence, as it had a coefficient of 0.25 . This was followed by Product that had a coefficient of 0.20 with a significance of 0.01 . The second order confirmatory of the tourists' demand was composed of Life Experience (Lifeexp), Recreation (Recreati), and Human Relations (Humanre). The highest demand of tourists was Human Relations, as it had a coefficient of 0.78. This was followed by Recreation that had a coefficient of 0.69 with a significance of 0.01 .

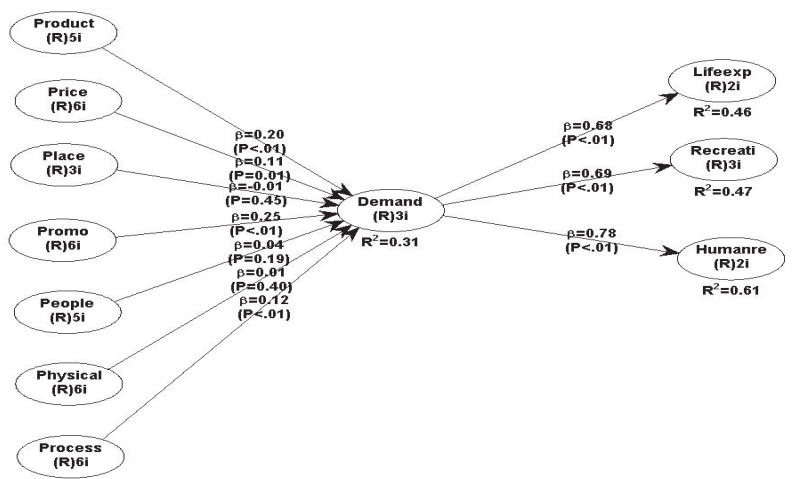

Fig. 3. Result of the confirmatory factor analysis

\section{Table 6}

Cross construct correlation

\begin{tabular}{|c|c|c|c|c|c|c|c|c|c|c|c|}
\hline Construct & Lifeexp & Recreati & Humanre & Demand & Product & Price & Place & Promo & People & Physical & Process \\
\hline Lifeexp & $(0.805)$ & & & & & & & & & & \\
\hline Recreati & 0.362 & $(0.743)$ & & & & & & & & & \\
\hline Humanre & 0.355 & 0.371 & $(0.897)$ & & & & & & & & \\
\hline Demand & 0.670 & 0.684 & 0.771 & $(0.725)$ & & & & & & & \\
\hline Product & 0.299 & 0.358 & 0.415 & 0.437 & $(0.753)$ & & & & & & \\
\hline Price & 0.365 & 0.209 & 0.294 & 0.360 & 0.441 & $(0.767)$ & & & & & \\
\hline Place & 0.138 & 0.414 & 0.127 & 0.249 & 0.332 & 0.290 & $(0.831)$ & & & & \\
\hline Promo & 0.265 & 0.510 & 0.266 & 0.438 & 0.420 & 0.339 & 0.485 & $(0.745)$ & & & \\
\hline People & 0.238 & 0.332 & 0.241 & 0.351 & 0.473 & 0.347 & 0.432 & 0.449 & $(0.782)$ & & \\
\hline Physical & 0.179 & 0.333 & 0.271 & 0.355 & 0.470 & 0.405 & 0.320 & 0.394 & 0.612 & $(0.729)$ & \\
\hline Process & 0.247 & 0.346 & 0.345 & 0.400 & 0.520 & 0.381 & 0.292 & 0.433 & 0.622 & 0.705 & $(0.737)$ \\
\hline
\end{tabular}

Note: Square roots of average variances extracted $\left(\mathrm{AVE}_{\mathrm{S}}\right)$ shown on diagonal. 
Source: Calculation

\section{Discussion and Recommendations}

In conclusion, in regarding the first order confirmatory, the marketing mix consisted of Product, Price, Promotion, and Process that affected the demand of tourists. Promotion had the most influence, as it had a coefficient of 0.25 while Product had a coefficient of 0.20 . The second order confirmatory comprised Life Experience, Recreation, and Human Relations. Human Relations had the most influence, as it had a coefficient of 0.78 while Recreation had a coefficient of 0.69 with a significance of 0.01 . The result of the empirical data analysis could support the hypothesis to be accepted that the tourism marketing mix affected the demand of tourists. The study also revealed the marketing promotion strategy due to the fact that current tourists mostly gave interest to online trends; for example, traveling by following the information about the rating and travel reviews. This conformed to the study of Chiwakunanan (2018) that tourists search for information about traveling in Thailand via online media, mainly Google, Facebook, and websites, respectively. Tourists use online media to search for attractions the most. This was followed by accommodation and the route or vehicle, respectively. Most of them enjoyed the information in the format of a blog or review post by previous users with details, and a blog or picture reviews.

The second was Product that comprised a beautiful product, various types of products, the popularity of tourist attractions, activities in the tourist attraction, facilities, tour service, and many other activities, tourists would be very interested. In compliance with the study of Kerdrit (2017), the marketing mix that tourists paid attention to the most was product and service while price and process took a major role in driving their supply once visiting in the area (Nonthapot, 2019; Nonthapot et al., 2019). For the marketing mix on Price, tourists gave importance to the appropriate and value-for-money price in their travel. Therefore, the activity of price setting for tourists would concern the travel behavior. The travel behavior of modern-day tourists tends for them to be backpackers, as they focus on simple living, saving, and worthiness. As for Process, at present, tourists give priority to travel that provides them with full comfortable facilities for relaxing. Furthermore, technological management takes an important role in tourism, as it acts as an assistant in planning a trip. Moreover, tourists become aware of their security of life and property, including facilities in the tourist attractions. Consequently, tourism marketing in terms of Process is totally important as well. The safety should be standardized with the installation of an advanced tourism management system, which would respond to the taste of modern tourists. Smartphones and the Internet world also have an important role in tourism by increasing the efficiency of products and services; for example, travel guide application, restaurant recommendation application, and QR code to introduce tourist attractions. In conformance with the study of Nonthapot (2019), from the marketing strategy direction for services, the price for a travel service must not be expensive, and process means to have good working and service processes including the use of technology for traveling.

On top of that, the 4Ps marketing mix comprising Product, Price, Promotion, and Process would affect the demand of tourists in the dimensions of Life Experience, Recreation, and Human Relations. Therefore, this would reflect the importance of tourism marketing on the demand of the behavior of tourists, whether it be the demand to travel for life experience; for instance, solo travel and exploration. Tourists desire to experience diverse environments to respond to their demand for making them enjoy the activities and to befriend the local people. The influence of the tourism marketing mix on the tourism demand nowadays has seen an emergence in quality and standard conservation in the tourist attraction and supply chain. As aforementioned, the related units in Thailand and the Lao People's Democratic Republic should proceed with these following activities:

1. The tourism sector of the state, private sectors and the tourism entrepreneurs in Thailand and the Lao People's Democratic Republic should have a marketing promotion for the various products; for example, development of infrastructure, landscape improvement, and appropriately creating diversity in the tourist attractions for greater tourism support. This would cover basic public utilities and convenient facilities for the better support of the tourism activities.

2. Give importance to the tourism market, particularly the marketing promotion that could influence the demand of tourists to visit the area. The budget for advertisements through the Internet, television, press, pamphlet, and brochure, should be arranged and to promote tourism through online media; such as, Facebook, Instagram, and bloggers. Furthermore, organize festivals with the intention to promote tourism in the provinces and attract tourists which would stimulate Thai and foreign tourists to travel more.

3. The price measurement should be appropriately regulated; for example, the entrance fee for attractions, price for the travel program, food price, accommodation price, and transport vehicle price to access the location. The worthiness of a reasonable price would directly impress tourists.

4. Management measurement should be supported. The measurement should cover security, good management, the administration and control systems in the tourist attractions in order to facilitate them and attract them to use the services.

\section{Acknowledgement}

This study is a part of Thailand Research Organizations Network (TRON) Project. The grant is supported by the National Research Council of Thailand, Thailand Research Fund (2016) and Khon Kaen University. 


\section{References}

Barghi, H., Kazemi, Z., Soory, F., \& Moasyebi, S. (2012). Evaluation and Ranking the effective components in rural tourism marketing with Marketing mix (7P) (case study: Amol, Babol, Babolsar and Sari Provinces). Journal of Regional Panning. 2(6), 31-41.

Burkhard, S. N. (7). travel trends for 2017 that will drive the global tourism industry. Tourism Management Perspectives, 10 , 27-36.

Chin, W. W. (1998a). The partial least squares approach to structural equation modeling. Modern methods for business research, 295(2), 295-336.

Chin, W.W. (1998b). Issues and opinion on structural equation modeling. MIS Quarterly, 22(1), 7-16.

Chiwakunanan, D. (2018). Influence of Reviewer in Online Media and the Decision to Travel in Thailand. Master of Business Administration, Faculty of Commerce and Accountancy, Thammasat University. [In Thai]

Gravetter, F. J., \& Wallnau, L. B. (2007). Statistics for the behavioral sciences ( ${ }^{\text {th }}$ Ed.). Thomson Wadsworth.

Hair, J. F., Hult, G. T. M., Ringle, C. M., \& Sarstedt, M. (2014). A primer on partial least squares structural equation modeling (PLS-SEM). Thousand Oaks: Sage.

Henseler, J., Ringle, C. M., \& Sinkovics, R. R. (2009). The use of partial least squares path modeling in international marketing. In New challenges to international marketing. Emerald Group Publishing Limited.

Ka-kan-dee, M., \& Nonthapot, S. (2020). Communication factors affecting the tourism services in the upper northeast of Thailand. Management Science Letters, 10(7), 1437-1444.

Kamau, F., Waweru, F. K., Lewa, P., \& Misiko, A.J. (2015). The effects of the marketing mix on choice of tourist accommodation by domestic tourists in Kenya. International Journal of Novel Research in Marketing Management and Economics, 2(2), 25 - 34.

Kerdrit, K. (2017). Marketing Mix Factors Influencing Tourists on Walking Street Tour in Phuket. Journal of Humanities and Social Sciences. 3(3). 74-83. [In Thai]

Kritsanaprakornkit, W. (2016). Lifestyle and Experiential Tourism.

Lauro, C., \& Vinzi, V. E. (2004). Some contributions to PLS Path Modeling and a system for the European Customer Satisfaction. Dipartimento di Matematica e Statistica, Universita Federico II di Napoli, 201-210.

ESIS (European Satisfaction Index System) 2001-2004, 201-210.

Magatef, S. G. (2015). The impact of tourism marketing mix elements on the satisfaction of inbound tourists to Jordan. International Journal of Business and Social Science, 6(7), 41-58.

Matchariyakul, N. (2016). Factors Affecting Thai Fully Independent Travelers' Decision to Taiwan. Master of Business Administration, Faculty of Commerce and Accountancy Thammasat University. [In Thai]

Ministry of Information, Culture and Tourism. (2018). 2018 Statistical Report on Tourism in Laos.

Ministry of Sports and Tourism. (2017). Tourist Statistics of Thailand 2016 (Northeastern

Region).

Ministry of Sports and Tourism. (2019). Tourism Situation in 2018 and 2019 Tendency.

National Tourism Policy Committee. (2018). Development Operation Plan for Tourism in Local Lifestyle Tourism Development of Kong River Zone 2017-2021.

Nonthapot, S. (2019). The impact of economic factors on street food consumer choice in Nong Khai Municipality, Nong Khai Province, Thailand. Management Science Letters, 9(13), 2337-2346.

Nonthapot, S., Thomya, W., Ka-Kan-Dee, M. and Srichaiyo, P. (2019). Factors Affecting the Demands of Tourists along the Mekong Riverside in Nong Khai and Bueng Kan Provinces in Connection to the Lao People's Democratic Republic: Explanatory Factor Analysis. Proceeding of the 1st International Conference on Economics, Business and Tourism.

Pengprapai, P. (2013). The Influence of Marketing Mix on Thai and Foreign Tourists' Interestin Socio-Cultural Tourism at Koh Phangan, Surat Thani. Master of Liberal Arts in Hospitality Industry and Tourism Management, University of Bangkok. [In Thai]

Pongwiritthon, R., Pakvipak, P., and Kantawongwan, B. (2016). Foreign Tourists' Behaviors and Marketing Mix towards "Discover Thainess" for Tourism Development Guidelines in the Northern Region of Thailand. Journal of Community Development Research (Humanities and Social Sciences), 9(3), 127-139. [In Thai]

RuelNovabos, C., Matiasa, A., \& Menab, M. (2015). How good is this destination website: A user-centered evaluation of provincial tourism websites. Procedia Manufacturing, 3(1), 3478-3485 Doi: 10.1016/j.promfg.2015.07.655.

Singsaktrakul, P. and Sermkarndee, P. (2013). The Study of Potentiality and Conservation Tourism Development Approach of Baan Thung-Maprang, Kuan Doan District and Baan Ton-Panan, Kuan Kalong District in Satun Province. Suthiparithat. 27(83): 97-112. Thanawan Vinaisatien (2017) [In Thai]

Suphanthong S., (2008). Services marketing mix affecting European tourist decision towards tourism services in Luang Prabang province, Lao People's Democratic Republic. The thesis of Master of Business Administration in Business Administration, Chiang Mai University. [In Thai]

Taburi, P. (2006). Marketing Strategies for Tourism in Roi-Et Province. Bachelor of Business Administration in Business Administration, Khon Khan University. [In Thai]

Tanmavad, K. (2002). Research Methodology In Economics. Bangkok: Ramkhamhaeng University Press. [In Thai] 
The Department of ASEAN Affairs, Ministry of Foreign Affairs. (2012). ASEAN Economic Community. Retrieved on 12 December 2019 from http://www.mfa.go.th/asean/th/customize/30641. [In Thai]

Wannathanom, C. (2009). Tourism Industry. Bangkok: SamLada. [In Thai]

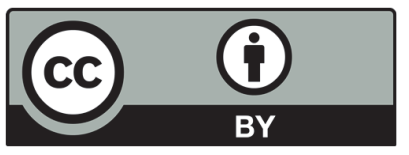

(C) 2020 by the authors; licensee Growing Science, Canada. This is an open access article distributed under the terms and conditions of the Creative Commons Attribution (CC-BY) license (http://creativecommons.org/licenses/by/4.0/). 